made of pandanas and palm leaves held up by poles cut from the forest. Each new-comer added on his hut to the last, at the same lime removing the partition, by this means turning the village into one endless habitation, broken by their respective doorways. The floors were of sand brought from the seashore, and, with the exception of the crudest of fireplaces, other furniture there was none. Skulls and the bones of departed relatives dangled in grass bags from the roof, blackened by the smoke of the fires. Now and again a wood pillow might be seen, otherwise the interior was bare. Outside there stood, ready for instant use, a stone club, a few spears-the heads fashioned from the leg-bones of pig or human beings-or a bow and a sheaf of arrows, to which weapons they flew on the slightest provocation.

The natives of this portion of New Guinea are divided into three classes or tribes. First come the people inhabiting the low-lying ground near the coast and extending inland for about twelve miles, and known to us as the coast natives. Then comes a strip of land practically uninhabited, and above this again, on a level with the headwaters of the Mimika, a race known to us as the up-river natives. Still further north, and inhabiting the foothills, are the pygmies. These three tribes are entirely distinct from one another, having no communication in the north and south direction-even though living on the same river-but passing freely to the east and west. The dividing line is hard and fast, and is not crossed except for occasional purposes of trade.

With the latitudes of Atabo at the coast and Parimau known, and the azimuth obtained, it was easy to fix all the points in the range from Carstenz in the east to Mount Darwin in the west. The height of Carstenz, formerly assumed to be about 18,000 feet, was found to have an altitude of rather more than 16,000 feet, while to the west three more great snow-peaks were discovered, with a height of about 15,500 feet, and these we named Mount Idenburg. Beyond and between these two mountains two other great snow-peaks were visible, evidence that the ground to the north does not fall abruptly away. But more interesting than all was the discovery that the great range, stretching from Carstenz in the east to the Charles Louis mountains in the west, a distance of eighty miles, formed one immense unbroken precipice, culminating in its greater sheer height at Mount Darwin. We were never in a position to measure with the theodolite a greater sheer height of more than 6500 feet, but from many views obtained while climbing, I have no hesitation in stating that the greatest perpendicular height is, at this spot, not less than 10,500 feet, or two miles.

The snow-line is at about 14,500 feet, the glaciers on Carstenz descending lower and falling over the precipice to the south. From a letter received from Lieut. Postema, the naval officer in charge of the survey of the Dutch Expedition on the Oetakwa river, I understand that he is of like opinion that Carstenz mountain is not climbable. The extreme wetness of this district is, without doubt, due to the great altitude and proximity of these mountains, the rainfall being in excess of any other portion of New Guinea.

To sum up the final results of the expedition: large and valuable collections of birds, mammals, reptiles, butterflies, and moths had been formed, together with botanical and ethnographical specimens; a new and unknown race of pygmies discovered, studied, measured, and photographed a range of mountains, containing the greatest precipice in the world, together with 3000 square miles of country, surveyed and mapped, new snow-mountains found, and many great rivers explored; and a long stretch of coast-line surveyed. We had accomplished the longest cross-country journey ever undertaken in Dutch New Guinea, i.e, eleven marches from the up-river camp, had proved the impossibility of the Mimika river as a line of advance to the Snows, and, on the other hand, the value of the great rivers to the east if the same goal is intended. From experience, and our heavy death-roll will bear me out, I have no hesitation in saying, first, that the land is an impossible one to any but a Papuan; and secondly. that, unless most carefully picked, no natives of the East Indies, with the exception of Dyaks from Borneo, are of the slightest value as carriers in South Dutch New Guinea.

NO. 2 I75, VOL. 87 ].

\section{WORKSHOP AND COLLEGE.}

$I^{\prime} \mathrm{I}$ is now agreed that engineering training should include scientific instruction and practical and commercial experience. But very divergent views are held as to the relative importance of the different components of such a training and as to the order and duration of each. We must recognise at once that the field of engineering employment is a very wide one, and that different capacities are required in different parts of that field. It is therefore in no way surprising that persons, whose opportunities of observation give them every right to express a definite opinion as to what is best for one special branch of engineering, have arrived at conclusions very different from those held by others, whose field of work has been in a different branch. No system of engineering training can be arranged to meet all special demands, and it is the object of such a conference as this to find out what is most essential in all courses of training and what modifications are practically possible to meet different cases.

First of all, I think it must be assumed that the engineering education we are specially charged to consider is that of young men whose aim it is to arrive ultimately at a professional status, such a status as membership of this institution implies. Their hope is to be employed ultimately in the design and control and direction of engineering work. Of course, some of them may fail in capacity or may lack opportunity, and may drift to one of the many more commercial occupations allied to engineering; and even there the knowledge they have acquired will be a valuable asset. But at the outset a professional career is aimed at, and the system of engineering education must be arranged to meet that condition. It is probably only by educating many that the few can be found who have the capacity and character necessary to achieve considerable advances and to do work of national importance.

Now, very few young men at eighteen can foresee into what line of employment they may be driven, and consequently the first or undergraduate stage of education must be broad, so as to fit students for widely different spheres of work.

Perhaps the greatest defect of engineering education at present is the want of more provision for the higher and more specialised education of the few students of real capacity discovered in the sifting process of an undergraduate course.

In spite of the general acceptance of the view that a study of scientific principles and their application is a necessary preliminary to a practical course in field or workshop, a certain jealousy of college education is still obvious in some practical engineers. While conceding in words that some scientific education is necessary to an engineer, they would, in fact, confine it to very elementary matters. They would greatly restrict the time given to it, and they are disposed to depreciate the value of any higher teaching, and even to regard it as mischievous and likely to unfit a man for the strenuous life of the manufacturing workshop.

I believe the idea that a college course unfits a man for practical work is a wholly mistaken one. There may be students who prove unfit for practical work in spite of college education. They would equally fail if their education was purely practical. There may be college courses, I am afraid it must be said there have been college courses, badly arranged, and teachers in colleges less competent than is desirable. But such things are inevitable. Nothing is more certain than that there has been a great improvement of college teaching of applied science in the last twenty years.

An employer who takes into his works college students is, I think, often disposed to expect from them an immediate availability which is unreasonable. It is not the main object of a college course to make a student acquainted with the details of any particular business; that is the proper object of the first year or two of practical work. It is not the main object of a college course to fit students specially for such work as will fall to them

1 Opening remarks at a Conference on Education and Training of Engineers (inint meeting of Sections II. and III., Scientific and Practical Training), held at the Institution of Civil Engineers, by Dr. W. C. Unwin, F.R.S., chairman of Section II 
while in the lowest rank of the profession. The college course must contemplate the fitting of a student for his whole career, and provide him with an intellectual equipment which will only gradually become useful as he rises to higher rank in his profession. The view of the employer who looks only to the immediate usefulness of the student is a short-sighted one.

Nevertheless, a college course is an unpractical and badly designed one if, at the end of it, a student is not more capable and useful from the first, in any type of workshop, than a lad without such a training. The college discipline is bad if he has not much more character and energy than the raw lad. His training has been a failure if he does not pick up the specialised details of any business to which he may be put far more rapidly than an untrained lad. I should like to suggest to those practical engineers who are implicitly, if not openly, hostile to college training, who would, at any rate, greatly restrict it, and who advocate lengthened periods of workshop apprenticeship, that they exaggerate the value of such workshop experience as an ordinary apprentice gets. I am not, of course, considering artisan apprentices, but young men expecting to rise to positions of trust. Here and there are works where special trouble is taken with apprentices; but in general apprentices are left to pick up what knowledge they can with very little help, and in many cases, I think, a good deal of their time is absolutely wasted. Some skill of handicraft is no doubt acquired. But the engineer works with his head, not with his hands, and manual skill is of use to him only in very exceptional cases.

I hope I do not in any way underrate the value, to mechanical engineers especially, of that kind of knowledge of materials, of tools, of processes, and of cost which can only be learned in the workshop. But I think practical engineers forget how little of this valuable knowledge really comes to the works apprentice. The engineer of higher rank who discusses matters with foremen and draughtsmen, who has responsibility for design and cost and is, moreover, in a position to know the reason of all decisions, is learning in the workshop all his life, and naturally sets a high value on the knowledge slowly acquired by years of constant and close observation. So high a value that perhaps he ignores the importance of the scientific knowledge which was, somewhere and by someone, applied in bringing his business to a state in which it can be carried on successfully as a mere manufacture. But the knowledge which comes to those in responsible positions is not open to the ordinary apprentice, and he learns slowly, if at all, unless he brings to the works such a knowledge of principles and methods that he can interpret for himself what he sees. No system of workshop apprenticeship can, I think, be considered satisfactory unless someone is specially charged with care of the apprentices, whose duty it should be to make sure that they have opportunity of seeing a great variety of work and of helping them over their difficulties.

I believe employers will find-some of them have found already - that they owe a debt to the colleges, and that the college-trained student will prove, with a minimum of special experience, a valuable assistant, and in some cases the originator of a real advance in practice. I should like to plead that in return the employer might be a little more ready to give college students a year or two years' run of the works, either without remuneration or with a small remuneration just enough for disciplinary purposes. I do not think there would be any loss in the case of a properly trained student, and the employer would in many cases find an assistant worth keeping and promoting.

\section{GOLD MINING IN THE TRANSVAAL. ${ }^{1}$}

$T H E$ discovery of gold on the Witwatersrand was made in the year 1885 . The growth of the field was at first slow. Some of the earliest workers believed that the auriferous gravel, exposed in shallow open workings, was a superficial deposit of the nature of the alluvial "placers" of California and Australia. The true character of the

1 Abridged from the nineteenth "Iames Forrest" lecture delivered on June 28 before the Institution of Civil Engineers by Dr. F. H. Hatch, vicepresident of the Institution of Mining and Metallurgy.

$$
\text { No. } 2175 \text {, VOL. } 87]
$$

conglomerate beds was, however, soon realised by those who were fortunate enough to possess some geological knowledge, and by 1887 stamp-mills were in operation, the output from the Witwatersrand mines for that year being $81,045 l$. From 1887 onward the progress has been rapid.

Down to the permanent water-level, at a vertical depth varying from 200 to 300 feet, the conglomerate beds were "free-milling," that is to say, the iron pyrites, with which the gold is intimately associated, had been destroyed by oxidation, thus setting free the gold. Below the watertable the colour of the rock changes from red to blue : the ore becomes pyritic; and the gold is no longer so amenable to recovery by amalgamation, as is the case with the oxidised ore. This was the first difficulty that had to be overcome. Up to the year I89o the treatment of the Rand ore had consisted of crushing in stamp-mills, and the recovery of $5^{\circ}$ to 60 per cent. of the gold, by amalgamation on mercury-coated copper plates. The tailings received no further treatment; they were considered to be valueless, and, where the ground permitted it, were allowed to flow away.

The successful introduction of the cyanide process in 1890 inaugurated a new era in the history of Rand gold mining. It is no exaggeration to say that the great success of the Witwatersrand gold industry is a direct result of the introduction of the cyanide process. For the majority of the mines, the gold won by this process represents the difference between profit and loss, and without it the profitable working of the vast quantity of low-grade banket now being mined on the Rand would be impossible.

At first the pulp from the stamp-mills was run into retaining dams, from which the sand was afterwards dug out and conveyed in Scotch carts or in mine-trucks for treatment in the cyanide vats. On account of the slimecontent, only 30 per cent. of the gold left in the pulp from the amalgamating tables was recovered, the remainder being in the untreated slimes and in the residues.

The next step was the introduction of hydraulic classifiers, by means of which a considerable proportion of the slime was eliminated and a sand product obtained, which could be run direct into leaching tanks.

A process was then evolved for the treatment of the slimes. It consisted in causing the slime, overflowing from the sand-collectors, to settle, by the addition of lime, the bulk of the water being subsequently removed by decantation. The concentrated slime so obtained was then agitated with cyanide solution, which was ultimately drawn off by decantation.

The separation of sand from slime by the old-fashioned inverted pyramidal form of hydraulic classifier, and the decantation method for the removal of water or cyanide solution from sand or slime, are now giving place to the use of diaphragm cones and vacuum filters. In the most modern plants the separation of sand and slime in a mill product is effected by feeding the mill-pulp into a coneshaped collector or diaphragm cone; the sand is drawn off as a thickened pulp from the bottom, while the slime flows over at the periphery, and after passing through a secondary washing cone is freed from most of its remain ing water on a Caldecott filter-table, which is a slowly rotating horizontal vacuum filter.

The treatment of slime has been much facilitated by the recent introduction of air-asitation tanks and vacuumfilters, which enable the enriched cyanide solution to be rapidly drawn off from the slime-residue and sent as a clear liquid to the extractor boxes. The precipitation of the gold was effected in the original MacArthur Forrest process by zinc shavings, and this method is still preferred for the rich solutions; but for weak solutions, such as are obtained in the treatment of slimes, zinc dust is employed as a precipitant.

One important result of the perfection of the slimestreatment process has been the introduction of fine grinding in tube-mills, with consequent increased extraction and shortened treatment period. Further, the adoption of tubemills has modified the function of the stamp-mill. Stamps are no longer employed for fine crushing, and amalgamation in the mortar-boxes has been completely abolished: and even such plate-amalgamation as took place in front of the stamp-mills has in many cases been done away with. Concurrently with the limitation of the effective range 